\title{
City-based action to reduce harmful alcohol use: review of
}

\section{reviews [version 1; peer review: 1 approved, 1 approved with}

\section{reservations]}

\author{
Peter Anderson (D1,2, Eva Jané-Llopis3,4, Omer Syed Muhammad Hasan4, \\ Jürgen Rehm (iD) 4-9
}

\footnotetext{
${ }^{1}$ Faculty of Health, Medicine and Life Sciences, Maastricht University, P. Debyeplein 1, Maastricht, $6221 \mathrm{HA}$, The Netherlands 2Institute of Health \& Society, Newcastle University, Baddiley-Clark Building, Richardson Road, Newcastle upon Tyne, NE2 4AX, UK ${ }^{3}$ ESADE Business School, Ramon Llull University, Av. Esplugues 92-96, Barcelona, 08034, Spain

${ }^{4}$ Institute for Mental Health Policy Research, CAMH, 33 Russell Street, Toronto, ON M5S 2S1, Canada

${ }^{5}$ Campbell Family Mental Health Research Institute, CAMH, 250 College Street, Toronto, ON M5T 1R8, Canada

${ }^{6}$ Institute of Medical Science (IMS) , University of Toronto, Medical Sciences Building,1 King's College Circle, Room 2374, Toronto, ON M5S 1A8, Canada

${ }^{7}$ Department of Psychiatry, University of Toronto, 250 College Street, 8th Floor, Toronto, ON M5T 1R8, Canada

${ }^{8}$ Dalla Lana School of Public Health, University of Toronto, 155 College Street, 6th Floor, Toronto, ON M5T 3M7, Canada

9Institute for Clinical Psychology and Psychotherapy, TU Dresden, Chemnitzer Str. 46, Dresden, 01187 , Germany
}

V1 First published: 29 Jan 2018, 7:120

https://doi.org/10.12688/f1000research.13783.1

Latest published: 05 Mar 2018, 7:120

https://doi.org/10.12688/f1000research.13783.2

\section{Abstract}

Background: The World Health Organization global strategy on alcohol called for municipal policies to reduce the harmful use of alcohol. Yet, there is limited evidence that documents the impact of city-level alcohol policies.

Methods: Review of reviews for all years to July 2017. Searches on OVID Medline, Healthstar, Embase, PsycINFO, AMED, Social Work Abstracts, CAB Abstracts, Mental Measurements Yearbook, Health and Psychosocial Instruments, International Pharmaceutical Abstracts, International Political Science Abstracts, NASW Clinical Register, and Epub Ahead of Print databases. All reviews that address adults, without language or date restrictions resulting from combining the terms ("review" or "literature review" or "review literature" or "data pooling" or "comparative study" or "systematic review" or "metaanalysis" or "pooled analysis"), and "alcohol", and "intervention" and ("municipal" or "city" or "community").

Results: Five relevant reviews were identified. Studies in the reviews were all from high income countries and focussed on the acute consequences of drinking, usually with one target intervention, commonly bars, media, or drink-driving. No studies in the reviews reported the impact of comprehensive city-based action. One community cluster randomized controlled trial in Australia, published after the reviews, failed to find convincing evidence of an impact of

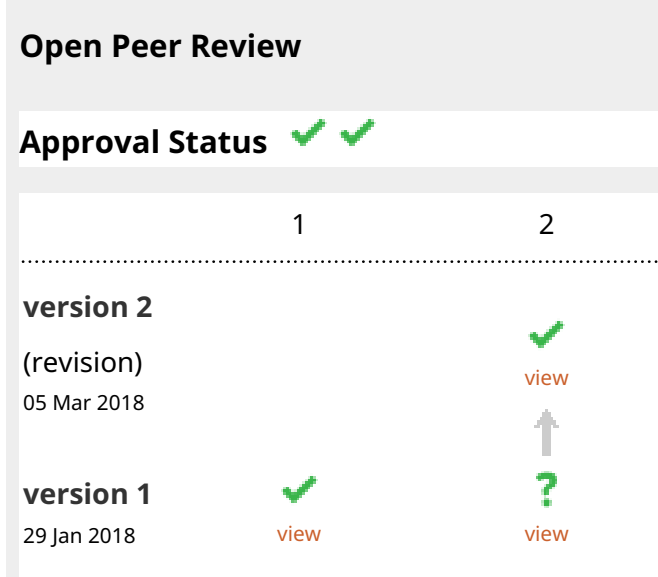

1. Joan Ramón Villalbí, Pompeu Fabra

University, Barcelona, Spain

2. R.H.L.M Bovens, Tilburg University, Tilburg, The Netherlands

Any reports and responses or comments on the article can be found at the end of the article. 
community-based interventions in reducing adult harmful use of alcohol.

Conclusions: To date, with one exception, the impact of adultoriented comprehensive community and municipal action to reduce the harmful use of alcohol has not been studied. The one exception failed to find a convincing effect. We conclude with recommendations for closing this evidence gap.

Keywords

Cities; Municipalities; communities; harmful use of alcohol

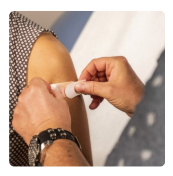

This article is included in the Sociology of

Health gateway.

Corresponding author: Peter Anderson (peteranderson.mail@gmail.com)

Author roles: Anderson P: Conceptualization, Formal Analysis, Writing - Original Draft Preparation, Writing - Review \& Editing; JanéLlopis E: Writing - Review \& Editing; Hasan OSM: Formal Analysis, Writing - Review \& Editing; Rehm J: Writing - Review \& Editing

Competing interests: JR, EJL and OSMH report no conflict of interest. PA has received fees from AB InBev Foundation.

Grant information: The author(s) declared that no grants were involved in supporting this work.

Copyright: ( 2018 Anderson P et al. This is an open access article distributed under the terms of the Creative Commons Attribution License, which permits unrestricted use, distribution, and reproduction in any medium, provided the original work is properly cited.

How to cite this article: Anderson P, Jané-Llopis E, Hasan OSM and Rehm J. City-based action to reduce harmful alcohol use: review of reviews [version 1; peer review: 1 approved, 1 approved with reservations] F1000Research 2018, 7:120

https://doi.org/10.12688/f1000research.13783.1

First published: 29 Jan 2018, 7:120 https://doi.org/10.12688/f1000research.13783.1 


\section{Introduction}

In response to the 2011 United Nations declaration on noncommunicable diseases (NCDs) (United Nations General Assembly, 2011; United Nations, 2014), the World Health Organization proposed a target to reduce the harmful use of alcohol by $10 \%$ between the years 2010 and 2025 (World Health Organization, 2014a), based on three possible indicators, adult per capita alcohol consumption, prevalence of heavy episodic drinking, and measures of alcohol-related morbidity and mortality (World Health Organization, 2014b).

The bulk of alcohol-related severe health problems, including mortality, occurs in middle age (Office for National Statistics, 2015), and, it is amongst this age group that policy and programme interventions are likely to bring the greatest health and productivity gains (Organisation for Economic Co-operation and Development, 2015). Heavy drinkers are responsible for the majority all alcohol-related harm (Rehm et al., 2013). It is also amongst this group, compared with lighter drinkers, that disproportionally greater health gains can be made for the same absolute reduction in alcohol consumption (Rehm \& Roerecke, 2013). Thus, if alcohol policy is to be most efficient in reducing the harmful use of alcohol, it should preferentially address adult drinkers, and, in particular, those who drink heavily.

Driving the NCD alcohol target are WHO's Global Strategy to reduce the harmful use of alcohol (World Health Organization, 2010), and WHO's three 'best buys' (World Economic Forum \& World Health Organization, 2011; World Health Organization, 2013). One of the ten target areas within the global strategy is community action, with a specific call to: "strengthen capacity of local authorities to encourage and coordinate concerted community action by supporting and promoting the development of municipal policies to reduce harmful use of alcohol, as well as their capacity to enhance partnerships and networks of community institutions and nongovernmental Organizations" (World Health Organization, 2010).

Cities are a potentially important setting and jurisdictional level for reducing NCDs (De Leeuw et al., 2015; Farrington et al., 2015). There is a range of evidence-based interventions that fall within municipal jurisdictional responsibility and which could be implemented at city level to reduce the harmful use of alcohol (Anderson \& Baumberg, 2006; Anderson et al., 2009; Anderson et al., 2012; Burton et al., 2017; Fitzgerald et al., 2016; Martineau et al., 2013). Despite a long history of calls for city-based policies and action plans (Mathrani \& Anderson, 1998; Ritson, 1995; World Health Organization, 1998), and an equally long history of research endeavour (Giesbrecht et al., 1990), a systematic review of the impact of alcohol policies, undertaken prior to the launch of the WHO global strategy, was unable to include community actions within its cost-effectiveness estimates, due to insufficient evidence of impact (Anderson et al., 2009).

Spurred by a target of a global beer producer to reduce the harmful use of alcohol by $10 \%$ over the five-year period 2016-2020 in pilot cities in at least nine different middle- and high-income countries (ABInBev, 2016), we have undertaken a review of reviews to investigate the potential impact of city-based action to reduce the harmful use of alcohol. In our review, we have focused on reviews that summarize the literature of comprehensive community and municipal action, often based on a municipal comprehensive strategy and action plan, as put forward by the World Health Organization (Anderson, 1991; Ritson, 1995). Because we anticipated very few such reviews, we have supplemented our findings with an overview of what could be implemented within a comprehensive municipal strategy to reduce the harmful use of alcohol, based on the published evidence base (Anderson \& Baumberg, 2006; Anderson et al., 2009; Anderson et al., 2012; Burton et al., 2017; Fitzgerald et al., 2016; Martineau et al., 2013).

\section{Methods}

During July 2017, we conducted a systematic literature search on OVID Medline, Healthstar, Embase, PsycINFO, AMED, Social Work Abstracts, CAB Abstracts, Mental Measurements Yearbook, Health and Psychosocial Instruments, International Pharmaceutical Abstracts, International Political Science Abstracts, NASW Clinical Register, and Epub Ahead of Print databases to identify reviews that addressed community and municipal alcohol interventions. With no language or date restrictions, the search used the following combination of terms: ("review" or "literature review" or "review literature" or "data pooling" or "comparative study" or "systematic review" or "meta-analysis" or "pooled analysis"), and "alcohol" and "intervention" and ("municipal" or "city" or "community"), supplemented with hand searches of included reviews.

Our inclusion criteria were reviews and overviews (whether or not systematic) that discussed the implementation of comprehensive policies and programmes to reduce the harmful use of alcohol at the community or municipal level. We excluded reviews of specific alcohol policy interventions, for example restrictions on hours and days of sale, that may or may not have been part of a city action plan. Two authors (OSMH and PA) independently reviewed titles and abstracts for selecting papers for full text review and selecting papers to include. Discrepancies, which only related to whether or not the publication addressed comprehensive approaches, were resolved with discussion. The result of the search, analysed during July 2017, is summarized in Figure 1. As only five relevant reviews were identified, three of which were by the same author, we did not attempt to analyze them for their quality, but rather describe their methods and findings.

\section{Results}

Only five relevant reviews were identified (Giesbrecht et al., 2014; Giesbrecht \& Greenfield, 2003; Giesbrecht \& Hayden, 2006; Gorman \& Speer, 1996; Toomey \& Lenk, 2001). Three included the same first author, and the most recent publication (Giesbrecht et al., 2014) included all publications of, and reached similar conclusions to, the previous four reviews. None of the reviews were systematic and none adhered to standard guidelines. Subsequent to the publication dates of the reviews, our search identified one further large randomized study of the effectiveness of community action (Shakeshaft et al., 2014). 


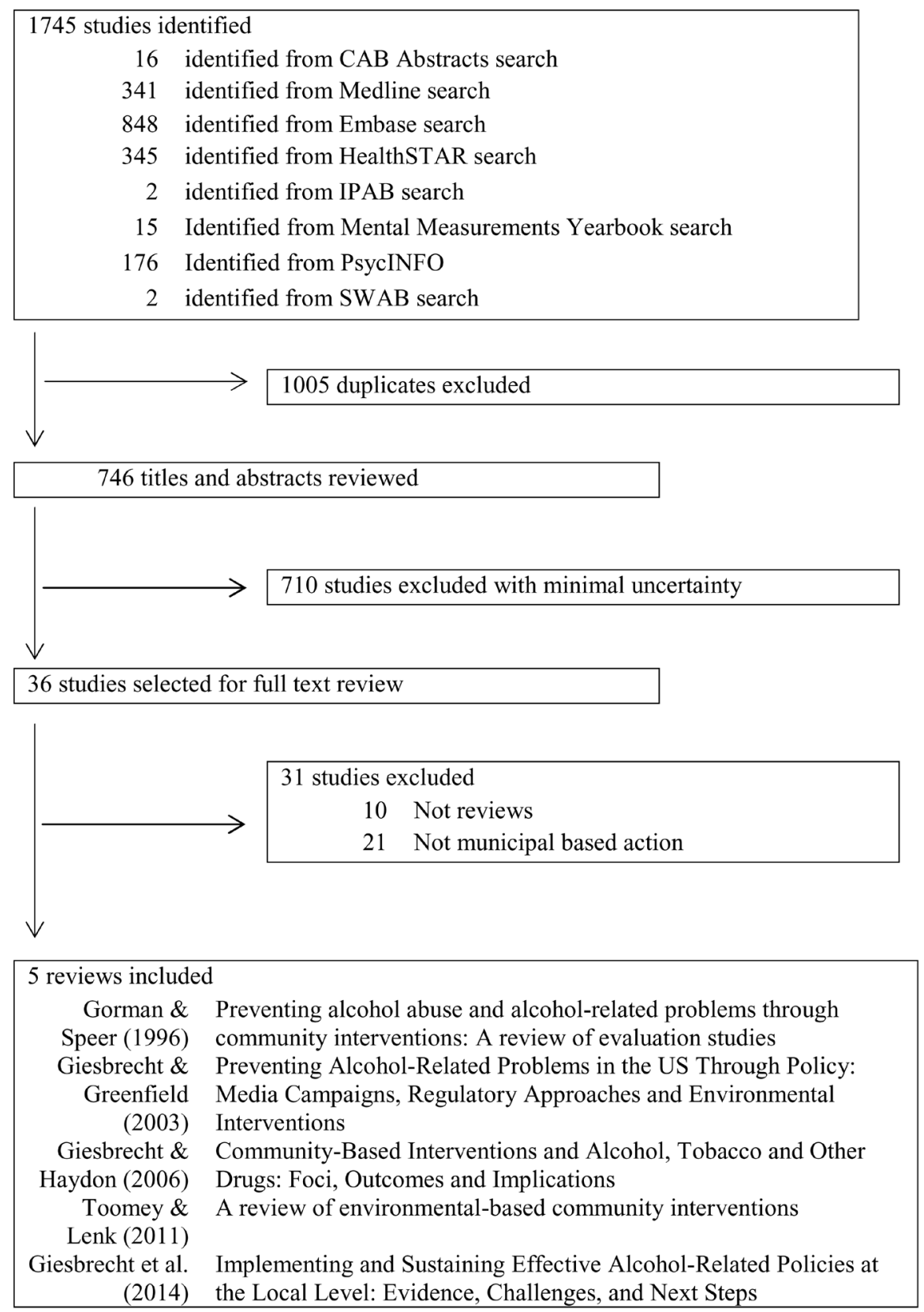

Figure 1. Flow chart for search of reviews.

Of the 23 individual studies mentioned in the 2014 review (Giesbrecht et al., 2014), twelve included adults, mostly with a focus on younger adults. Six were from North America, two were from Nordic countries, and four were from Australia/New Zealand. Four of the 12 studies targeted bars, three media campaigns, two drink-driving, one overall access, one a specific location (a beach), and one primary health care-based brief advice programmes. No studies reported comprehensive community or municipal interventions. The four bar studies found an effect in reducing violence, which tapered off over time. The three media studies found no impact. The two drink-driving studies led to reduced alcohol-involved traffic crashes. The access and location study led to reductions in the harmful use of alcohol, but the brief advice initiative did not.

The large study, outside of the reviews, was a randomized trial comprising 20 communities in Australia that each had populations of 5,000-20,000 inhabitants (Shakeshaft et al., 2014). Communities were pair-matched, and one member of each pair was randomly allocated to the experimental group. Thirteen interventions were implemented in the experimental communities from 2005 to 2009: community engagement; general practitioner training in 
alcohol screening and brief intervention (SBI); feedback to key stakeholders; media campaign; workplace policies/practices training; school-based intervention; general practitioner feedback on their prescribing of alcohol medications; community pharmacybased SBI; web-based SBI; Aboriginal Community Controlled Health Services support for SBI; Good Sports program for sports clubs; identifying and targeting high-risk weekends; and hospital emergency department-based SBI. The study failed to detect an impact of the interventions in reducing the harmful use of alcohol in routine data, but found a significant reduction of average alcohol use in surveys. Unfortunately, the study appeared under powered for the routine data, and had low response rates to measurement surveys. The community interventions were not able to be fully comprehensive and were not able to include a range of potentially impactful interventions, including sales taxes and restrictions on availability. Further, no process evaluation was reported; thus, whether or not the included interventions were implemented as planned, or the extent to which they were implemented is not reported.

One of the five reviews that we identified included a summary of feasible intervention options at the local and municipal level (Giesbrecht \& Haydon, 2006). We have included and expanded on these in Table 1, adding an overview of the evidence base (Anderson \& Baumberg, 2006; Anderson et al., 2009; Anderson et al., 2012; Burton et al., 2017; Fitzgerald et al., 2016; Martineau et al., 2013), with implementation illustrations at the city level. Dependent on jurisdictional responsibilities, city-level interventions that might have a meaningful contribution to reducing the harmful use of alcohol include sales taxes, restrictions on density of outlets and days and hours of sale, drink-drive restrictions, and scale-up of individual level advice and treatment programmes

Table 1. Feasible adult-oriented policies and programmes implementable at city level dependent on jurisdictional responsibilities, with evidence of impact and opportunity for city implementation.

\begin{tabular}{|c|c|c|}
\hline Policy measure & Evidence of impact & Opportunity for city implementation \\
\hline \multicolumn{3}{|l|}{ Pricing policies } \\
\hline Alcohol taxes & $\begin{array}{l}\text { Effective } \\
\text { Systematic reviews and meta-analyses find that increases in } \\
\text { the price and taxation of alcohol reduce consumption and } \\
\text { alcohol-related harm for all groups of drinkers, and in high, } \\
\text { middle and low-income countries (Anderson et al., 2009; } \\
\text { Dhalwani, 2011; Elder et al., 2010; Fogarty, 2008; } \\
\text { Gallet, 2007; Sornpaisarn et al., 2013; Wagenaar et al., 2009; } \\
\text { Wagenaar et al., 2010; Xu \& Chaloupka, 2011). }\end{array}$ & $\begin{array}{l}\text { Many cities have opportunity to set alcohol } \\
\text { beverage sales taxes, which can bring in } \\
\text { municipal revenues (KPMG LLP, 2016). }\end{array}$ \\
\hline \multicolumn{3}{|l|}{ Access policies } \\
\hline Outlet density & $\begin{array}{l}\text { Effective } \\
\text { Systematic reviews (Bryden et al., 2012; Campbell et al., 2009; } \\
\text { Gmel et al., 2016; Holmes et al., 2014; Livingston et al., 2007; } \\
\text { Popova et al., 2009) and individual studies (Fone et al., 2016; } \\
\text { Morrison et al., 2016; Richardson et al., 2015) find that greater } \\
\text { alcohol outlet density is associated with increased alcohol } \\
\text { consumption and harms, including injuries, violence and crime. }\end{array}$ & $\begin{array}{l}\text { Licensing of alcohol sales outlets allows local } \\
\text { governments to control where alcohol is sold to } \\
\text { the public, with restrictions on density related to } \\
\text { less crime (de Vocht et al., 2016). }\end{array}$ \\
\hline Days and hours of sale & $\begin{array}{l}\text { Effective } \\
\text { Systematic reviews find that days and hours of sale are } \\
\text { related to alcohol consumption and harms (Hahn et al., 2010; } \\
\text { Middleton et al., 2010; Wilkinson et al., 2016). Individual } \\
\text { studies find that restrictions on hours of sale reduce } \\
\text { harm (Duailibi et al., 2007; Kypri et al., 2014; } \\
\text { Rossow \& Norström, 2011). }\end{array}$ & $\begin{array}{l}\text { Licensing of alcohol sales outlets allows local } \\
\text { governments to control when alcohol is sold } \\
\text { to the public, with restrictions on hours of sale } \\
\text { related to less harm (de Vocht et al., 2016; } \\
\text { Wittman, 2016a; Wittman, 2016b). }\end{array}$ \\
\hline \multicolumn{3}{|l|}{ Bar policies } \\
\hline $\begin{array}{l}\text { Training of bar staff, } \\
\text { responsible serving } \\
\text { practices, security staff } \\
\text { in bars and safety- } \\
\text { oriented design of the } \\
\text { premise }\end{array}$ & $\begin{array}{l}\text { Mixed effectiveness } \\
\text { A systematic review found limited impact unless backed-up } \\
\text { by police enforcement and licence inspectors (Ker \& Chinnock, } \\
\text { 2008). }\end{array}$ & $\begin{array}{l}\text { Drinking environments can be foci of alcohol- } \\
\text { related harms (Hughes \& Bellis, 2012). } \\
\text { Ongoing enforcement is the required ingredient } \\
\text { to reduce harm in drinking environments } \\
\text { (Brännström et al., 2016; Florence et al., 2011; } \\
\text { Månsdotter et al., 2007; Wallin et al., 2001; } \\
\text { Warpenius et al., 2010; Trolldal et al., 2013). }\end{array}$ \\
\hline \multicolumn{3}{|l|}{ Advertising policies } \\
\hline Volume of advertising & $\begin{array}{l}\text { Effective } \\
\text { Systematic reviews find associations between volume of } \\
\text { advertising exposure and alcohol-related consumption and } \\
\text { harm (Bryden et al., 2012; Booth et al., 2008; Gallet, 2007; } \\
\text { Stautz et al., 2016). }\end{array}$ & $\begin{array}{l}\text { Cities have the opportunity of restricting } \\
\text { advertising, including billboards, in the public } \\
\text { places that they own or through the public } \\
\text { services, such as transportation, that they provide } \\
\text { (Fullwood et al., 2016; Swensen, 2016). }\end{array}$ \\
\hline
\end{tabular}




\section{Drink-drive restrictions}

Sobriety checkpoints and unrestrictive

(random) breath testing
Effective

Systematic reviews and meta-analyses find that both introducing and expanding sobriety checkpoints and random breath testing result in reduced alcohol-related injuries and fatalities (Bergen et al., 2014; Erke et al., 2009; Shults et al., 2001), enhanced with mass-media campaigns (Elder et al., 2004; Yadav \& Kobayashi, 2015).

Designated driver campaigns Ineffective

A systematic review did not find evidence for designated driver programmes in reducing the prevalence of people drink driving or being a passenger with a drink driver (Ditter et al., 2005)

\section{Screening, advice and treatment}

Digital interventions

\section{Effective}

A systematic review found that digital interventions were just as effective as face-to-face interventions in reducing alcohol consumption and related harm (Beyer et al., 2015; Kaner et al., 2015).

Primary health care

\section{Effective}

Systematic reviews and meta-analyses find a positive impact of screening and brief advice programmes on alcohol consumption, mortality, morbidity, alcohol-related injuries, alcohol-related social consequences, healthcare resource use and laboratory indicators of harmful alcohol use (O'Donnell et al., 2014).

There is stronger evidence of effectiveness for primary health care-based screening and brief advice programmes than for emergency care (Nilsen et al., 2008), general hospital settings (McQueen et al., 2011), obstetric or antenatal care

(Doggett et al., 2005), and pharmacy settings (Brown et al., 2016).

Systematic reviews and meta-analyses find that implementation strategies are effective in increasing the volume of primary health care screening and brief advice activity (Anderson et al., 2004; Keurhorst et al., 2015).

Workplace

Largely ineffective

Systematic reviews of workplace-based programmes (Webb et al., 2009) and workplace-based screening and brief advice programmes find little evidence for reducing consumption and harm (Schulte et al., 2014).

Secondary health care Effective

Systematic reviews find that psycho-social (Magill \& Ray, 2009; Smedslund et al., 2011; The British Psychological Society \& The Royal College of Psychiatrists, 2011) and pharmacological therapies (Rösner et al., 2010a; Rösner et al., 2010b;

The British Psychological Society \& The Royal College of

Psychiatrists, 2011) are effective in treating heavy drinking.

\section{Education and information}

\section{School-based} programmes campaigns

Changing social norms

\section{Product reformulation}

Alcohol content and packaging

\section{Ineffective}

Systematic reviews find that reported benefits are seen only in the short term and are often not replicated (Foxcroft \& Tsertsvadze, 2011; Strom et al., 2014)

\section{Ineffective}

Systematic reviews find evidence of little or no sustained impact of public education campaigns in changing drinking behaviour (Martineau et al., 2013), with the exception of drink driving (Elder et al., 2004).

Limited evidence

Overviews suggest that alcohol-related social norms can be changed by campaigns, particularly when related to behaviour changes (Miller \& Prentice, 2016).
Cities have the opportunity to step-up sobriety checkpoints and random breath testing

Whist a seemingly attractive approach, there is insufficient evidence to warrant widespread investment in designated driver campaigns. (Voas, 2008).

Off-the-shelf applications can be deployed at city level (Crane et al., 2015; Garnett et al., 2015), enhanced with context awareness and use of ecological momentary assessments (Freisthler et al., 2014; Morgenstern et al., 2014; Wray et al., 2014).

Tailored screening and brief advice programmes embedded within community and municipal action are more likely to be scaled-up (Anderson et al., 2017; Heather 2006).

Although business cases are made for workplace-based programmes (Martinic, 2015), the evidence appears insufficient to justify a citybased investment.

Treatment services can be embedded within comprehensive care pathways (NICE, 2016) at the city level.
Whilst a popular intervention, and a necessary part of school education, investment in schoolbased education programmes should be proportionate, given the evidence for lack of effectiveness.

Media campaigns should focus on changing behaviour in relation to existing programmes, such as drink driving (Yadav \& Kobayashi, 2015), rather than acting in isolation, where there is evidence of ineffectiveness.

Social norms campaigns should focus on topics that are the subject of behaviour change programmes, such as drink driving (Perkins et al., 2010).

Cities could set limits on beverage container sizes (Jones-Webb et al., 2011; McKee et al., 2012).

\section{Limited evidence}

A systematic review indicates the theoretical likelihood that reductions in the average alcohol content of beverages would reduce alcohol-related harm (Rehm et al., 2016). 
(Organisation for Economic Co-operation and Development, 2015).

\section{Discussion}

Cities can be natural units for promoting health (de Leeuw et al., 2015; Farrington et al., 2015), including reducing the harmful use of alcohol (Mathrani \& Anderson, 1998). Although not necessarily having the full jurisdictional responsibilities of national governments for all health policy issues, they often have greater flexibility and are an important site for innovative environmental measures that make healthier choices easier choices, shifting social norms in the process (Reeve et al., 2015). Cities are members of many networks, including Healthy Cities networks, which are natural vehicles for deployment to full scale globally.

This review has identified a suite of evidence-based policies and programmes that could, dependent on jurisdictional responsibilities, be implemented at the city level to reduce the harmful use of alcohol. Indeed, some of the studies identified by the reviews that focused on one particular programme area, for example enforcement of bar regulations, stepped up drink-driving activities, and strengthened access regulations, found some impacts in reducing the harmful use of alcohol. However, only one study evaluated a suite of interventions, and found no convincing evidence of impact. This study, though, was unable to include a range of potential impactful interventions (price and availability), and did not report implementation fidelity of the included interventions Shakeshaft et al., 2012).

We have not been able to find evidence for the effective impact of comprehensive municipal action plans in reducing the harmful use of alcohol. There is, thus, dissonance between calls for action and evidence. This contrasts with other topic areas, such as smoking (Moreland-Russell et al., 2016; Perlman et al., 2016), obesity (Reeve et al., 2015; Sisnowski et al., 2016), and physical activity (Giles-Corti et al., 2016; Sallis et al., 2016a; Sallis et al., 2016b; Stevenson et al., 2016), where there is experience of coordinated city action and a supporting evidence base.

We conclude our paper by discussing how this dissonance might be reduced. First, there are needs for multi-city studies that test the impact of developed and implemented municipal action plans in reducing the harmful use of alcohol. To match the WHO target of a $10 \%$ reduction in the harmful use of alcohol over a 15-year time frame, recognizing the importance of addressing adults, and, in particular heavy drinkers, the evidence base indicates that municipal action plans need to include, where jurisdictional authority allows, all of: sales taxes to increase the price of alcohol; reductions in the availability of alcohol through restrictions on outlet density and days and hours of sale; intensive implementation of drink drive restrictions through sobriety checkpoints and/or unrestrictive (random) breath testing; and, widespread deployment and scale-up of health care based screening and brief advice and treatment programmes, see Table 1. Municipal action plans should not be based on public education or mass media programmes alone, as these have been found to be ineffective in reducing the harmful use of alcohol (Martineau et al., 2013).

Ideally, multi-city studies should be set up as randomized trials with control cities in different sites with sufficient sample size with respect to both cities and individuals within cities to test whether the municipal action plans work. While this may be difficult to realize, given that such randomized trials would have very high costs, and there are not many examples of sufficiently powered community trials in the literature, a different design in combining national aggregate and individual level data could be used to achieve better control (Gmel et al., 2004). Longitudinal individual level data could be collected by drawing representative samples from the adult population in the cities, with an oversampling of heavier drinkers. This would allow an analysis of how the city actions affect individual drinking trajectories, as recommended by a number of authors (Fitterer et al., 2015; Holmes et al., 2015). The evaluation should triangulate the individual cohort data with the aggregate-level data, and with other routinely collected data, such as alcohol-attributable hospitalizations (Shakeshaft et al., 2014) to test if the municipal actions lead to a reduction in the harmful use of alcohol. Wastewaterbased epidemiology can be used to contrast alcohol consumption between implementation cities and comparator cities (Ryu et al., 2016). Logic models should be developed to undertake process evaluation (Moore et al., 2015) to ascertain implementation fidelity and to identify and empirically demonstrate effective best practices to reduce harmful consumption of alcohol that could be adopted for scale-up in other cities and countries (Barker et al., 2016).

\section{Competing interests}

JR, EJL and OSMH report no conflict of interest. PA has received fees from AB InBev Foundation.

\section{Grant information}

The author(s) declared that no grants were involved in supporting this work.
ABInBev: Our Global Smart Drinking Goals. (acessed 26 July 2017). Reference Source

Anderson P: The Management of Drinking Problems. WHO Regional Publications, European series No. 32, Copenhagen, World Health Organization Regional Office for Europe. (In English, French, German, Russian and Hungarian), 1991.
Anderson $\mathrm{P}$, Baumberg B: Alcohol in Europe: A public health perspective. London: Institute of Alcohol Studies, 2006. Reference Source

Anderson P, Chisholm D, Fuhr DC: Effectiveness and cost-effectiveness of policies and programmes to reduce the harm caused by alcohol. Lancet. 2009; 
373(9682): 2234-46.

PubMed Abstract | Publisher Full Text

Anderson $\mathrm{P}$, Laurant $\mathrm{M}$, Kaner $\mathrm{E}$, et al.: Engaging general practitioners in the management of hazardous and harmful alcohol consumption: results of a meta-analysis. J Stud Alcohol. 2004; 65(2): 191-199.

PubMed Abstract | Publisher Full Text

Anderson P, Møller L, Galea G (eds.): Alcohol in the European Union.

Copenhagen, Denmark: World Health Organization. 2012.

Reference Source

Anderson P, O'Donnell A, Kaner E, et al.: Scaling-up primary health care-based prevention and management of alcohol use disorder at the municipal level in middle-income countries in Latin America: Background and pre-protocol for a three-country quasi-experimental study [version 2; referees: 3 approved with reservations]. F1000Res. 2017; 6: 311

PubMed Abstract | Publisher Full Text | Free Full Text

Barker PM, Reid A, Schall MW: A framework for scaling up health interventions: lessons from large-scale improvement initiatives in Africa. Implement Sci. 2016; 11(1): 12

PubMed Abstract | Publisher Full Text | Free Full Text

Bergen G, Pitan A, Qu S, et al.: Publicized sobriety checkpoint programs: a community guide systematic review. Am J Prev Med. 2014; 46(5): 529-39. PubMed Abstract | Publisher Full Text

Beyer F, Maniatopoulos G, Kaner E, et al.: Engagement with digital interventions for reducing hazardous or harmful alcohol consumption in communitydwelling populations: A systematic review. Prospero; 2015.

Reference Source

Booth A, Meier P, Stockwell T, et al:: Independent review of the effects of alcohol pricing and promotion. Part A: systematic reviews. [Internet]. School of Health and Related Research. 2008, [cited 2014 Nov 3].

Reference Source

Brännström L, Trolldal B, Menke M: Spatial spillover effects of a community action programme targeting on-licensed premises on violent assaults: evidence from a natural experiment. J Epidemiol Community Health. 2016; 70(3): 226-30.

PubMed Abstract | Publisher Full Text

Brown TJ, Todd A, O'Malley C, et al.: Community pharmacy-delivered interventions for public health priorities: a systematic review of interventions for alcohol reduction, smoking cessation and weight management, including meta-analysis for smoking cessation. BMJ Open. 2016; 6(2): e009828. PubMed Abstract | Publisher Full Text | Free Full Text

Bryden A, Roberts B, McKee M, et al.: A systematic review of the influence on alcohol use of community level availability and marketing of alcohol. Health Place. 2012; 18(2): 349-357.

PubMed Abstract | Publisher Full Tex

Burton R, Henn C, Lavoie D, et al.: A rapid evidence review of the effectiveness and cost-effectiveness of alcohol control policies: an English perspective.

Lancet. 2017; 389(10078): 1558-1580.

PubMed Abstract | Publisher Full Tex

Campbell CA, Hahn RA, Elder R, et al:: The effectiveness of limiting alcohol outlet density as a means of reducing excessive alcohol consumption and alcohol-related harms. Am J Prev Med. 2009; 37(6): 556-69.

PubMed Abstract | Publisher Full Text

Crane D, Garnett C, Brown J, et al.: Behavior change techniques in popula alcohol reduction apps: content analysis. J Med Internet Res. 2015; 17(5): e118. PubMed Abstract | Publisher Full Text | Free Full Text

De Leeuw E, Green G, Spasnwick L, et al.: Policymaking in European healthy cities. Health Promot Int. 2015; 30(Suppl 1): i18-i31.

PubMed Abstract | Publisher Full Text

de Vocht $F$, Heron J, Angus $C$, et al: Measurable effects of local alcohol licensing policies on population health in England. $J$ Epidemiol Community Health. 2016; 70(3): 231-237.

PubMed Abstract | Publisher Full Text | Free Full Text

Dhalwani N: A Review of Alcohol Pricing and its Effects on Alcoho Consumption and Alcohol-Related Harm. J Pak Med Stud. 2011; 1(1): 23-27. Reference Source

Ditter SM, Elder RW, Shults RA, et al.: Effectiveness of designated driver programs for reducing alcohol-impaired driving: a systematic review. $A m \mathrm{~J}$ Prev Med. 2005; 28 (5 Suppl): 280-87.

PubMed Abstract | Publisher Full Tex

Doggett C, Burrett SL, Osborn DA: Home visits during pregnancy and after birth for women with an alcohol or drug problem. Cochrane Database Syst Rev. 2005; (4): CD004456.

PubMed Abstract | Publisher Full Tex

Duailibi S, Ponicki W, Grube J, et al:: The effect of restricting opening hours on alcohol-related violence. Am J Public Health. 2007; 97(12): 2276-280.

PubMed Abstract | Publisher Full Text | Free Full Text

Elder RW, Lawrence B, Ferguson A, et al:: The effectiveness of tax policy interventions for reducing excessive alcohol consumption and related harms. Am J Prev Med. 2010; 38(2): 217-29.

PubMed Abstract | Publisher Full Text | Free Full Text

Elder RW, Shults RA, Sleet DA, et al:: Effectiveness of mass media campaigns for reducing drinking and driving and alcohol-involved crashes: a systematic review. Am J Prev Med. 2004; 27(1): 57-65

PubMed Abstract | Publisher Full Text

Erke A, Goldenbeld C, Vaa T: The effects of drink-driving checkpoints on crashes--a meta-analysis. Accid Anal Prev. 2009; 41(5): 914-923.

PubMed Abstract | Publisher Full Text

Farrington JL, Faskunger J, Mackiewicz K: Evaluation of risk factor reduction in a European City Network. Health Promot Int. 2015; 30(Suppl 1): i86-i98.

PubMed Abstract | Publisher Full Text

Fitterer JL, Nelson TA, Stockwell T: A Review of Existing Studies Reporting the Negative Effects of Alcohol Access and Positive Effects of Alcohol Control

Policies on Interpersonal Violence. Front Public Health. 2015; 3: 253.

PubMed Abstract | Publisher Full Text | Free Full Text

Fitzgerald N, Angus K, Emslie C, et al:: Gender differences in the impact of population-level alcohol policy interventions: evidence synthesis of systematic reviews. Addiction. 2016; 111(10): 1735-47.

PubMed Abstract | Publisher Full Text

Florence C, Shepherd J, Brennan I, et al.: Effectiveness of anonymised information sharing and use in health service, police, and local government partnership for preventing violence related injury: experimental study and time series analysis. BMJ. 2011; 342: d3313.

PubMed Abstract | Publisher Full Text | Free Full Tex

Fogarty J: The demand for beer, wine and spirits: insights from a meta-analysis approach. AAWE. (accessed April 29, 2016). 2008.

Reference Source

Fone D, Morgan J, Fry R, et al.: Change in alcohol outlet density and alcoholrelated harm to population health (CHALICE): a comprehensive record-linked database study in Wales. Public Health Res. 2016; 4(3)

PubMed Abstract | Publisher Full Text

Foxcroft DR, Tsertsvadze A: Universal school-based prevention programs for alcohol misuse in young people. Cochrane Database Syst Rev. 2011; (5): CD009113.

PubMed Abstract | Publisher Full Text

Freisthler B, Lipperman-Kreda S, Bersamin M, et al:: Tracking the When,

Where, and With Whom of Alcohol Use: Integrating Ecological Momentary

Assessment and Geospatial Data to Examine Risk for Alcohol-Related

Problems. Alcohol Res. 2014; 36(1): 29-38.

PubMed Abstract | Free Full Text

Fullwood MD, Basch $\mathrm{CH}$, LeBlanc M: Implications for visually stimulating advertisement on NYC subway platforms. Int J Adolesc Med Health. 2016; 29(5): pii: /j/ijamh.2017.29.issue-5/ijamh-2015-0112/ijamh-2015-0112.xml.

PubMed Abstract | Publisher Full Text | Free Full Text

Gallet CA: The demand for alcohol: a meta-analysis of elasticities. Aust J Agric Resour Econ. 2007: 51(2): 121-135.

Publisher Full Text

Garnett C, Crane D, West R, et al: Identification of Behavior Change Techniques and Engagement Strategies to Design a Smartphone App to Reduce Alcohol

Consumption Using a Formal Consensus. JMIR Mhealth Uhealth. 2015; 3(2): e73. PubMed Abstract | Publisher Full Text | Free Full Text

Giesbrecht N, Bosma LM, Juras J, et al.: Implementing and Sustaining Effective Alcohol-Related Policies at the Local Level: Evidence, Challenges, and Next

Steps. World Medical \& Health Policy. 2014; 6(3): 203-230.

Publisher Full Text

Giesbrecht N, Greenfield TK: Preventing Alcohol-Related Problems in the US

Through Policy: Media Campaigns, Regulatory Approaches and Environmenta Interventions. J Prim Prev. 2003; 24(1): 63-104.

Publisher Full Text

Giesbrecht N, Haydon E: Community-Based Interventions and Alcohol, Tobacco and Other Drugs: Foci, Outcomes and Implications. Drug Alcohol Rev. 2006;

25(6): 633-46.

PubMed Abstract | Publisher Full Text

Giesbrecht N, Pranovi P, Wood L: Impediments to Changing Local Drinking Practices: Lessons from a Prevention Project. In Research, Action, and the Community: Experiences in the Prevention of Alcohol and Other Drug Problems, eds. N. Giesbrecht, P. Conley, R. Denniston, L. Gliksman, H. Holder, A. Pederson, R. Room, and M. Shain. Rockville, MD: Office for Substance Abuse Prevention, 1990; 161-82

Reference Source

Giles-Corti B, Vernez-Moudon A, Reis R, et al:: City planning and population health: a global challenge. Lancet. 2016; 388(10062): 2912-2924.

PubMed Abstract | Publisher Full Text

Gmel G, Holmes J, Studer J: Are alcohol outlet densities strongly associated with alcohol-related outcomes? A critical review of recent evidence. Drug Alcohol Rev. 2016; 35: 40-54.

PubMed Abstract | Publisher Full Text

Gmel G, Rehm J, Room R: Contrasting individual level and aggregate level studies in alcohol research? Combining them is the answer. Addict Res Theory 2004: 12(1): 1-10.

Publisher Full Text

Gorman DM, Speer PW: Preventing alcohol abuse and alcohol-related problems through community interventions: A review of evaluation studies.

Psychology \& Health. 1996; 11(1): 95-131.

Publisher Full Text 
Hahn RA, Kuzara JL, Elder R, et al.: Effectiveness of policies restricting hours of alcohol sales in preventing excessive alcohol consumption and related harms. Am J Prev Med. 2010; 39(6): 590-604.

PubMed Abstract | Publisher Full Text | Free Full Text

Heather N editor: WHO Collaborative Project on Identification and Management of Alcohol-related Problems in Primary Health Care. Report to the World Health Organisation on Phase IV: Development of Country-wide Strategies for Implementing Early Identification and Brief Intervention in Primary Health Care. Geneva: World Health Organisation, Department of Mental Health and Substance Abuse: 2006

Reference Source

Holmes J, Angus C, Meier PS: UK alcohol industry's "billion units pledge": Interim evaluation flawed. BMJ. 2015; 350: h1301.

PubMed Abstract | Publisher Full Text

Holmes J, Guo Y, Maheswaran R, et al:: The impact of spatial and temporal availability of alcohol on its consumption and related harms: a critical review in the context of UK licensing policies. Drug Alcohol Rev. 2014; 33(5): 515-25. PubMed Abstract | Publisher Full Text | Free Full Text

Hughes K, Bellis MA: Drinking environments. In Anderson P, L. Møller and G. Galea Eds. Alcohol in the European Union: Consumption, Harm and Policy Approaches,. World Health Organization, Copenhagen. 2012.

Reference Source

Jones-Webb R, McKee P, Toomey T, et al.: Regulating malt liquor in urban areas in the United States. Contemp Drug Probl. 2011; 38(1): 41-59.

Publisher Full Text

Kaner EF, Beyer FR, Brown J, et al:: Personalised digital interventions for reducing hazardous and harmful alcohol consumption in community-dwelling populations. Cochrane Database Syst Rev. 2015

Publisher Full Text

Ker K, Chinnock P: Interventions in the alcohol server setting for preventing injuries. Cochrane Database Syst Rev. 2008; (3): CD005244.

Publisher Full Text

Keurhorst M, van de Glind I, Bitarello do Amaral-Sabadini M, et al:: Determinants of successful implementation of screening and brief interventions for hazardous and harmful alcohol consumption in primary healthcare. A systematic review and meta-regression analysis. Addiction. 2015; 110: 877-900. KPMG LLP: City of Toronto - Revenue Options Study -FINAL.docx. 2016. Reference Source

Kypri K, McElduff $P$, Miller $P$ : Restrictions in pub closing times and lockouts in Newcastle, Australia five years on. Drug Alcohol Rev. 2014; 33(3): 323-26. PubMed Abstract | Publisher Full Text

Livingston M, Chikritzhs T, Room R: Changing the density of alcohol outlets to reduce alcohol-related problems. Drug Alcohol Rev. 2007; 26(5): 557-66. PubMed Abstract | Publisher Full Text

Magill M, Ray LA: Cognitive-behavioral treatment with adult alcohol and illicit drug users: a meta-analysis of randomized controlled trials. J Stud Alcohol Drugs. 2009; 70(4): 516-527.

PubMed Abstract | Publisher Full Text | Free Full Text

Månsdotter AM, Rydberg MK, Wallin E, et al:: A cost-effectiveness analysis of alcohol prevention targeting licensed premises. Eur J Public Health. 2007; 17(6): 618-23.

PubMed Abstract | Publisher Full Text

Martineau F, Tyner E, Lorenc T, et al:: Population-level interventions to reduce alcohol-related harm: an overview of systematic reviews. Prev Med. 2013; 57(4): 278-96.

PubMed Abstract | Publisher Full Text

Martinic M: A business case for reducing alcohol-related harm in the workplace. In OECD. Tackling Harmful Alcohol Use. Paris, OECD Publishing. 2015; 133-140.

Publisher Full Text

Mathrani S, Anderson P: Guidelines for city action on alcohol. Copenhagen, World Health Organization, 1998, (accessed 31 Aug 2016).

Reference

McKee PA, Nelson TF, Toomey TL, et al.: Adopting local alcohol policies: a case study of community efforts to regulate malt liquor sales. Am J Health Promot. 2012; 26(3): e86-94.

PubMed Abstract | Publisher Full Text

McQueen J, Howe TE, Allan L, et al:: Brief Interventions for Heavy Alcohol Users Admitted to General Hospital Wards. Cochrane Database Syst Rev. 2011; 8 : CD005191.

PubMed Abstract | Publisher Full Tex

Middleton JC, Hahn RA, Kuzara JL, et al.: Effectiveness of policies maintaining or restricting days of alcohol sales on excessive alcohol consumption and related harms. Am J Prev Med. 2010; 39(6): 575-89.

PubMed Abstract | Publisher Full Text | Free Full Text

Miller DT, Prentice DA: Changing norms to change behavior. Annu Rev Psychol. 2016; 67: 339-61.

PubMed Abstract | Publisher Full Text

Moore GF, Audrey S, Barker M, et al.: Process evaluation of complex

interventions: Medical Research Council guidance. BMJ. 2015; 350: h1258.

PubMed Abstract | Publisher Full Text | Free Full Text

Moreland-Russell S, Combs T, Schroth K, et al.: Success in the city: the road to implementation of Tobacco 21 and Sensible Tobacco Enforcement in New York City. Tob Control. 2016; 25(Suppl 1): i6-i9.

PubMed Abstract | Publisher Full Text | Free Full Text

Morgenstern J, Kuerbis A, Muench F: Ecological momentary assessment and alcohol use disorder treatment. Alcohol Res. 2014; 36(1): 101-109.

PubMed Abstract | Free Full Text

Morrison C, Ponicki WR, Gruenewald PJ, et al:: Spatial relationships between alcohol-related road crashes and retail alcohol availability. Drug Alcohol Depend. 2016; 162: 241-244.

PubMed Abstract | Publisher Full Text | Free Full Text

NICE: Alcohol Use Disorders Overview. 2016, Accessed 18 October 2016. Reference Source

Nilsen P, Baird J, Mello MJ, et al:: A Systematic Review of Emergency Care Brief Alcohol Interventions for Injury Patients. J Subst Abuse Treat. 2008; 35(2): $184-201$.

PubMed Abstract | Publisher Full Text

O'Donnell A, Anderson P, Newbury-Birch D, et al.: The impact of brief alcohol interventions in primary healthcare: a systematic review of reviews. Alcohol Alcohol. 2014; 49(1): 66-78.

PubMed Abstract | Publisher Full Text | Free Full Text

Office for National Statistics: Alcohol related deaths in the United Kingdom: registered 2013. 2015. (accessed 4 Dec 2016).

Reference Source

Organisation for Economic Co-operation and Development: Tackling Harmful Alcohol Use: Economics and Public Health Policy. Paris: Organisation for Economic Co-operation and Development, 2015.

Reference Source

Perkins HW, Linkenbach JW, Lewis MA, et al:: Effectiveness of social norms media marketing in reducing drinking and driving: a statewide campaign. Addict Behav. 2010; 35(10): 866-74.

PubMed Abstract | Publisher Full Text | Free Full Text

Perlman SE, Chernov C, Farley SM, et al:: Exposure to Secondhand Smoke Among Nonsmokers in New York City in the Context of Recent Tobacco Control Policies: Current Status, Changes Over the Past Decade, and National Comparisons. Nicotine Tob Res. 2016; 18(11): 2065-2074.

PubMled Abstract | Publisher Full Text

Popova S, Giesbrecht N, Bekmuradov D, et al:: Hours and days of sale and density of alcohol outlets: impacts on alcohol consumption and damage: a systematic review. Alcohol Alcohol. 2009; 44(5): 500-16.

PubMed Abstract | Publisher Full Text

Reeve B, Ashe M, Farias R, et al:: State and Municipal Innovations in Obesity Policy: Why Localities Remain a Necessary Laboratory for Innovation. Am Public Health. 2015; 105(3): 442-450.

PubMed Abstract | Publisher Full Text | Free Full Text

Rehm J, Lachenmeier DW, Llopis EJ, et al:: Evidence of reducing ethanol content in beverages to reduce harmful use of alcohol. Lancet Gastroenterol Hepatol. 2016; 1(1): 78-83.

PubMed Abstract | Publisher Full Text

Rehm J, Roerecke M: Reduction of drinking in problem drinkers and all-cause mortality. Alcohol Alcohol. 2013; 48(4): 509-513.

PubMed Abstract | Publisher Full Text

Rehm J, Shield KD, Gmel G, et al.: Modeling the impact of alcohol dependence on mortality burden and the effect of available treatment interventions in the European Union. Eur Neuropsychopharmacol. 2013; 23(2): 89-97.

PubMed Abstract | Publisher Full Text

Richardson EA, Hill SE, Mitchell R, et al:: Is local alcohol outlet density related to alcohol-related morbidity and mortality in Scottish cities? Health Place. 2015; 33: $172-80$.

PubMed Abstract | Publisher Full Text | Free Full Text

Ritson B: Community and municipal action on alcohol. Copenhagen, World Health Organization regional Office for Europe. 1995.

Reference Source

Rösner S, Hackl-Herrwerth A, Leucht S, et al:: Acamprosate for alcohol dependence. Cochrane Database Syst Rev. 2010a; (9): CD004332. PubMed Abstract | Publisher Full Text

Rösner S, Hackl-Herrwerth A, Leucht S, et al.: Opioid antagonists for alcohol dependence. Cochrane Database Syst Rev. 2010b; 12: CD001867.

PubMed Abstract | Publisher Full Text

Rossow I, Norström T: The Impact of Small Changes in Bar Closing Hours on Violence. The Norwegian Experience from 18 Cities. Addiction. 2011; 107(3): 530-537.

PubMed Abstract | Publisher Full Text | Free Full Text

Ryu Y, Barcelóc D, Barrone LP, et al.: Comparative measurement and quantitative risk assessment of alcohol consumption through wastewaterbased epidemiology: An international study in $\mathbf{2 0}$ cities. Sci Total Environ. 2016; 565: $977-983$

PubMed Abstract | Publisher Full Text

Sallis JF, Bull F, Burdett $R$, et al.: Use of science to guide city planning policy and practice: how to achieve healthy and sustainable future cities. Lancet. 2016a: 388(10062): 2936-2947.

PubMed Abstract | Publisher Full Text

Sallis JF, Cerin E, Conway TL, et al.: Physical activity in relation to urban 
environments in 14 cities worldwide: a cross-sectional study. Lancet. 2016b 387(10034): 2207-17

PubMed Abstract | Publisher Full Tex

Schulte B, O'Donnell AJ, Kastner S, et al.: Alcohol screening and brief intervention in workplace settings and social services: a comparison of literature. Front Psychiatry. 2014; 5: 131

PubMed Abstract | Publisher Full Text | Free Full Text

Shakeshaft A, Doran C, Petrie D, et al: Alcohol Action in Rural Communities (AARC) project: detailed description of the interventions and their costs. Monograph No. 64. Sydney: National Drug and Alcohol Research Centre. 2012. Reference Source

Shakeshaft A, Doran C, Petrie D, et al:: The Effectiveness of Community Action in Reducing Risky Alcohol Consumption and Harm: A Cluster Randomised Controlled Trial. PLOS Med. 2014; 11(3): e1001617.

PubMed Abstract | Publisher Full Text | Free Full Text

Shults RA, Elder RW, Sleet DA, et al:: Reviews of Evidence Regarding Interventions to Reduce Alcohol-Impaired Driving. Am J Prev Med. 2001; 21(4 Suppl): $66-88$

PubMed Abstract | Publisher Full Text

Sisnowski J, Street JM, Braunack-Mayer A: Targeting population nutrition through municipal health and food policy: implications of New York City's experiences in regulatory obesity prevention. Food Policy. 2016; 58: 24-34.

Publisher Full Text

Smedslund G, Berg RC, Hammerstrom KT, et al.: Motivational interviewing for substance abuse. Cochrane Database Syst Rev. 2011; 5: CD008063. PubMed Abstract | Publisher Full Text

Sornpaisarn B, Shield K, Cohen J, et al.: Elasticity of alcohol consumption, alcohol-related harms, and drinking initiation in low- and middle-income countries: a systematic review and meta-analysis. International Journal of Drug and Alcohol Research. 2013; 2(1): 1-14.

Publisher Full Text

Stautz K, Brown KG, King SE, et al.: Immediate effects of alcohol marketing communications and media portrayals on consumption and cognition: a systematic review and meta-analysis of experimental studies. BMC Public Health. 2016; 16: 465 .

Publisher Full Text

Stevenson M, Thompson J, de Sá TH, et al.: Land use, transport, and population health: estimating the health benefits of compact cities. Lancet 2016; 388(10062): 2925-2935.

PubMed Abstract | Publisher Full Text | Free Full Text

Strom HK, Adolfsen F, Fossum S, et al:: Effectiveness of school-based preventive interventions on adolescent alcohol use: a meta-analysis of randomized controlled trials. Subst Abuse Treat Prev Policy. 2014; 9: 48. PubMed Abstract | Publisher Full Text | Free Full Text

Swensen G: Public space and alcohol advertising: exploratory study of the role of local government. Int J Alcohol Drug Res. 2016; 5(3): 117-123.

Publisher Full Text

The British Psychological Society, The Royal College of Psychiatrists: Alcohol-use disorders: The NICE guideline on diagnosis, assessment and management of harmful drinking and alcohol guidance. National Clinical Practice Guideline

115. NICE. 2011, (accessed Nov 9, 2016).

Reference Source

Toomey TL, Lenk KM: A review of environmental-based community interventions. Alcohol Res Health. 2001; 34(2): 163-166.

PubMed Abstract | Free Full Text

Trolldal B, Brännström L, Paschall MJ, et al.: Effects of a multi-component responsible beverage service programme on violent assaults in Sweden. Addiction. 2013; 108(1): 89-96.

PubMed Abstract | Publisher Full Text

United Nations General Assembly: Political declaration of the High-level Meeting of the General Assembly on the Prevention and Control of Non-communicable Diseases. 2011

Reference Source

United Nations: High-level meeting on the comprehensive review and assessment of the progress achieved in the prevention and control of noncommunicable diseases (NCDs). 2014

Reference Source
Voas RB: A New Look at NHTSA's Evaluation of the 1984 Charlottesville Sobriety Checkpoint Program: Implications for Current Checkpoint Issues. Traffic Inj Prev. 2008; 9(1): 22-30.

PubMed Abstract | Publisher Full Text

Wagenaar AC, Salois MJ, Komro KA: Effects of beverage alcohol price and tax levels on drinking: a meta-analysis of 1003 estimates from 112 studies. Addiction. 2009; 104(2): 179-190.

PubMed Abstract | Publisher Full Text

Wagenaar AC, Tobler AL, Komro KA: Effects of alcohol tax and price policies on morbidity and mortality: a systematic review. Am J Public Health. 2010; 100(11): 2270-78.

PubMed Abstract | Publisher Full Text | Free Full Text

Wallin E, Norstrom T, Andreasson S: Alcohol prevention targeting licensed premises: a study of effects on violence. J Stud Alcohol Drugs. 2001; 72 723-30.

Warpenius $\mathrm{K}$, Holmila M, Mustonen $\mathrm{H}$ : Effects of a community intervention to reduce the serving of alcohol to intoxicated patrons. Addiction. 2010; 105(6): 1032-40.

PubMed Abstract | Publisher Full Tex

Webb G, Shakeshaft A, Sanson-Fisher R, et al.: A systematic review of workplace interventions for alcohol-related problems. Addiction. 2009; 104(3): 365-377.

PubMed Abstract | Publisher Full Tex

Wilkinson C, Livingston M, Room R: Impacts of changes to trading hours of liquor licences on alcohol-related harm: a systematic review 2005-2015. Public Health Res Pract. 2016; 26(4): pii: 2641644.

PubMed Abstract | Publisher Full Text

Wittman FD: Halfway there - the evolution of local alcohol control in California: Part I: the system as it has developed. Int J Alcohol Drug Res. 2016a; 5(3): 101-107.

Publisher Full Text

Wittman FD: Halfway there - the evolution of local alcohol control in California: Part II: Stages and factors in development, 1980-2-15. Int J Alcohol Drug Res. 2016b; 5(3): 109-116.

Publisher Full Text

World Economic Forum, World Health Organization: From burden to "best buys": Reducing the economic impact of non-communicable diseases in low- and middle-income countries. Davos, Switzerland: World Economic Forum. 2011. Reference Source

World Health Organization: Community Action to Prevent Alcohol Problems. Papers presented at the Third Symposium on Community Action Research, Greve in Chianti, Italy, September 25-29, 1995, Copenhagen: World Health Organization 1998.

Reference Source

World Health Organization: Global Action Plan for the Prevention and Control of NCDs 2013-2020. Geneva, Switzerland: World Health Organization. 2013. Reference Source

World Health Organization: Global status report on noncommunicable diseases 2014. Attaining the nine global noncommunicable diseases targets; a shared responsibility. Geneva, Switzerland: World Health Organization. 2014a.

Reference Source

World Health Organization: Global strategy to reduce the harmful use of alcohol. Geneva, Switzerland: World Health Organization. 2010.

Reference Source

World Health Organization: Noncommunicable Diseases Global Monitoring

Framework: Indicator Definitions and Specifications. 2014b.

Reference Source

Wray TB, Merrill JE, Monti PM: Using ecological momentary assessment (EMA) to assess situation-level predictors of alcohol use and alcohol-related consequences. Alcohol Res. 2014; 36(1): 19-27.

PubMed Abstract | Free Full Text

Xu X, Chaloupka FJ: The effects of prices on alcohol use and its consequences. Alcohol Res Health. 2011; 34(2): 236-45.

PubMed Abstract | Free Full Text

Yadav RP, Kobayashi M: A systematic review: effectiveness of mass media campaigns for reducing alcohol-impaired driving and alcohol-related crashes. BMC Public Health. 2015; 15(1): 857

PubMed Abstract | Publisher Full Text | Free Full Text 


\section{Open Peer Review}

\section{Current Peer Review Status:}

\section{Version 1}

Reviewer Report 26 February 2018

https://doi.org/10.5256/f1000research.14982.r31220

(C) 2018 Bovens R. This is an open access peer review report distributed under the terms of the Creative Commons Attribution License, which permits unrestricted use, distribution, and reproduction in any medium, provided the original work is properly cited.

\section{R.H.L.M Bovens}

Tilburg University, Tilburg, The Netherlands

I think this paper contributes very much to the discussion what to do about reducing alcohol problems in society among adult people.

It shows in the world there is little effort to focus these problems in an integrative way, using evidence based interventions as the 'three best buys': reducing advertisement, availability and raising taxes.

Authors did their job accurate.

I just have one comment:

The paper focuses on adult people. In the research were, as far as I know only reviews that address adults.

Why do the authors do not discuss the gap between the policy used focussing youth and the policy focussing adults?

For example the research carried out by Karen Schelleman at your own university shows small evidence for effect of city-based actions in the Netherlands (Karen Schelleman-Offermans, R. Knibbe, E. Kuntsche: Preventing Adolescent Alcohol Use: Effects of a Two-Year Quasi-Experimental Community Intervention Intensifying Formal and Informal Control. Journal of Adolescent Health 54(3) November 2013; Karen Schelleman-Offermans, R. Knibbe, M. Derickx \& H. van de Mheen: A Process Evaluation of a Community Intervention to Reduce Youth Drinking. Sucht 59(5):249-259 . January 2013).

The thing is many countries are focusing only on youth, I think that is the main reason there are so few researches about community interventions in the adult world.

This is the reason why I chose 'Partly' in the first question: accurate: Yes, but in my view not complete.

Paying attention to the gap between the policy regarding youth and regarding adults would improve the paper seriously.

Is the work clearly and accurately presented and does it cite the current literature? Partly 
Is the study design appropriate and is the work technically sound?

Yes

Are sufficient details of methods and analysis provided to allow replication by others? Yes

If applicable, is the statistical analysis and its interpretation appropriate?

Not applicable

Are all the source data underlying the results available to ensure full reproducibility? Yes

Are the conclusions drawn adequately supported by the results?

Yes

Competing Interests: No competing interests were disclosed.

I confirm that I have read this submission and believe that I have an appropriate level of expertise to confirm that it is of an acceptable scientific standard, however I have significant reservations, as outlined above.

Author Response 01 Mar 2018

Peter Anderson, Maastricht University, P. Debyeplein 1, The Netherlands

Author response: Thank you for this important comment. We have added a paragraph to the discussion that stresses, from a health perspective, the importance of addressing adults as opposed to adolescents. We noted that there is considerably more research that focuses on community-based action to reduce the harmful use of alcohol among adolescents rather than among adults and suggested that this is due to an undue focus of existing alcohol policy on youth-oriented actions, that have tended to strengthen during the first decade of the $21^{\text {st }}$ century, at the expense of policies that would address adults.

Competing Interests: No competing interests were disclosed.

Reviewer Report 05 February 2018

https://doi.org/10.5256/f1000research.14982.r30366

(C) 2018 Villalbí J. This is an open access peer review report distributed under the terms of the Creative Commons Attribution License, which permits unrestricted use, distribution, and reproduction in any medium, provided the original work is properly cited.

Joan Ramón Villalbí

Public Health Agency of Barcelona (ASPB), Biomedical Research Centre Network for Epidemiology 
and Public Health (CIBERESP), Health and Life Sciences Unit, Pompeu Fabra University, Barcelona, Spain

This is a relevant paper providing needed perspectives on interventions to reduce the harm caused by alcohol. It is presented as a review of reviews, but in fact it goes a bit beyond it, as the contents of table 1 are in themselves a valuable side-product.

I think the paper is acceptable to be indexed in its current form, and may be useful to many practitioners.

Is the work clearly and accurately presented and does it cite the current literature? Yes

Is the study design appropriate and is the work technically sound?

Yes

Are sufficient details of methods and analysis provided to allow replication by others? Yes

If applicable, is the statistical analysis and its interpretation appropriate?

Not applicable

Are all the source data underlying the results available to ensure full reproducibility? Yes

Are the conclusions drawn adequately supported by the results?

Yes

Competing Interests: No competing interests were disclosed.

I confirm that I have read this submission and believe that I have an appropriate level of expertise to confirm that it is of an acceptable scientific standard. 
The benefits of publishing with F1000Research:

- Your article is published within days, with no editorial bias

- You can publish traditional articles, null/negative results, case reports, data notes and more

- The peer review process is transparent and collaborative

- Your article is indexed in PubMed after passing peer review

- Dedicated customer support at every stage

For pre-submission enquiries, contact research@f1000.com 